\title{
EFFECT OF SOME BIOINSECTICIDES ON SOME BIOLOGICAL ASPECTS OF THE PARASITOID MICROPLITIS RUFIVENTRIS KOK.
}

\author{
ABD-EL-ATTY, S.F. \\ Plant Protec.Res.Inst. ARC, Dokki, Giza, , Egypt. \\ (Manuscript received 11 January 2014)
}

\begin{abstract}
Laboratory experiments were undertaken to study the relationships between the solitary endoparasitoid, Microplitis rufiventris Kok.and the Egyptian cotton leaf worm, Spodoptera littoralis (Boisd.) when fed on castor bean leaves treated with the bacterial, Bacillus thuringiensis Berl. And the fungus, Beauveria bassiana (Bals.)Vuill. with both entomopathogens Total developmental period, longevity of adults, six ratios and the percent of adults emergence of endoparasitoid, $M$. rufiventris were affected by treating host bacterial, B.thuringiensis caused mortality percentage of egg-larvae, using three rates recoded 20,28 and $40 \%$, respectively, compared with $4.0 \%$ in the control. For the fungus, $B$. bassiana, it was 8,12 and $20 \%$, respectively, compared with $1.0 \%$ in the control. But the biocide bioclean, B. thuringiensis $+B$. bassiana recorded 12,28 and $32 \%$, respectively, compared with $2 \%$ in the check. Emergence percentage of the parasitoid, M.rufiventris males were 32, 44 and $28 \%$, respectively compared with $48 \%$ in the control. For females it was 32,16 and $26 \%$, respectively and $22 \%$ in the check. In case of fungus, $B$. bassiana the male's emergence percentage was 40,52 and $52 \%$, respectively, and $92 \%$ in the control. Percentage of Females was 40 , 20 and $8 \%$ respectively, compared with $44 \%$ in the control. For M.rufiventris males parasitized the larvae of $S$. littorals that fed on castor bean leaves and treated with bioclean, B.thuringiensis + B. bassiana was 66,48 and $60 \%$ respectively, and it was $44 \%$ in control . For females it was 18,12 and $4 \%$, respectively, compared with $46 \%$ in the control.
\end{abstract}

\section{INTRODUCTION}

The cotton leaf worm, Spodoptera littoralis is the major pest that causes damages to cotton plants as well as other fields and vegetable crops in Egypt. Great efforts have been made to control this pest mechanically and chemically using insecticides belonging to different insecticidal groups that known to endanger man, farm animals and the environment. The solitary endoparasitoid, Microplitis rufiventris Kok. (Braconidae: Hymemoptera) was recorded on S. littoralis in Egypt (Hegazi et al. 1977 and Tawfik et al. 1980). Now a day the entomopathogens, Bacillus. thuringiensis and Beauveria bassiana have been used to control the pest, (AL-Tahtaway and Abalees, 1972).The interaction between the host-parasitoid system and the entomopathogenic micro organisms has been paid little attention (El-Sufty1978, Temerak 1982 and El-Maghraby 1984). There are also reports of indirect effects of 
host pathogens on parasitoids where the host dies from an infection before the parasitoid complete their development (Laigo and Tamashiro, 1967).Therefore, the insect-parasitoid-pathogen interactions could be either beneficial or detrimental to ultimate control of the insect, depending upon their effect on each other. The interactions between the host-parasitoid system and the entomopathogenic microorganisms have been paid attention (Bell et al.1974, El-Sufty1978, Hamed, 1979, Temark, 1980, Salama et al.1982, and El-Maghraby et al.1988). Knowledge of interactions among hosts, parasitoid and pathogens is crucial not only for fundamental ecological understanding, but also for attempts to conserve threatened communities or to control pests with natural enemies (Hochberg et al.1990). The biological control is one of the most effective means of achieving insect control (Pedigo, 2004).On the other hand Radwan et al.(2004) used biocides for control the cotton leaf worm,Spdoptera littoralis, these materials may not cause any kind of pollution on the environment.

Therefore, the present investigation aimed to study the effect of the entomopathogens ( $B$. thuringiensis and $B$. bassiana) in case it was used alone or as mixture on biological aspects of the parasitoid, M. rufiventris, and the biological control agent of $S$. littoralis.

\section{MATERIALS AND METHODS}

\section{Bio insecticides formulations:}

\section{1- Ecotch-Bio.:}

Bacteria: Bacillus thuringiensis var- kurstaki. Application rate $300 \mathrm{~g} / \mathrm{fedden}$.

2- Biofly: Fungus, Beavaria bassiana.Application of rate $300 \mathrm{~cm} / \mathrm{fedden}$.

3- Bioclean: (Bacteria and Fungi).Application rate700g /feddan.

(Mixture of $400 \mathrm{~g} \mathrm{~B}$. bassina and $300 \mathrm{~g}$ of $B$. thuringiensis).

Rearing of Spodoptera littoralis and Microplitis rufiventris:

\section{1- Rearing of S. littoralis:}

Egg masses of the cotton leaf worm, S. littoralis were collected from the cotton and vegetable fields in Zagazig region. The pest several generations. Larvae were fed on castor bean leaves, Ricinus communis according with Abd-El-Atty (1995) under $26.5 \pm 0.5^{\circ} \mathrm{C}$ and $70 \pm 5 \%$ R.H. at an incubator.

\section{2- Rearing of M. rufiventris:}

Larvae of $S$. littoralis parasitized by $M$. rufiventris were collected from the same fields aboe-mentioned.These larvae were placed in cylindrical glass jars (4Kg). The jars were covered by muslin cloth, held with rubber bands and provided with filter 
paper at the bottom of the jar to absorb excess moisture. Larvae of S. littoralis were reared on fresh castor bean leaves that were provided daily until pupation of the parasitoid. The pupae were kept in clean jars $(1 \mathrm{Kg})$ till emergence. Females of $M$. rufiventris (2-5 days) old after copulation were used to parasitize $S$. littoralis larvae. Adult of parasitoids, M. rufiventris were provided daily with honey and drops of water. Parasitism of $2^{\text {nd }}$ instar larvae of $S$. littorals were exposed to individually a female parasitoid. Fifty larvae were used (in five replicates) at each treatment rate from the biocides (half, recommended and double) rates. There after left until pupation and emergence of the parasitoid larvae or death. Were recorded biological aspects points such as:

-Egg-larvae stage of parasitoid, M. rufiventris.

- Percent mortality of different stages of parasitoid, M. rufiventris.

- Percent pupation of parasitoid, M. rufiventris.

- Total developmental period of parasitoid, M. rufiventris.

- \%Emergence of parasitoid, M. rufiventris.

- Longevity period males and females of parasitoid, M. rufiventris.

- Sex ratio of males and females of parasitoid, M. rufiventris.

\section{3- Statistical analysis:}

The obtained data were statistically analyzed according to complete randomized block design. The appropriate methods were used for analysis of data according to Duncan's (1955) and Snedecor (1970) by computer program 3003copyright 1986 Cohort Software P.O.Box.1194,Berkeley CA947s1.(costat program methods).

\section{RESULTS AND DISCUSSION}

\section{1- Effect of Bacteria, Bacillus thuringiensis Kurstaki on some biological aspects of the parasitoid, Microplitis rufiventris:}

\section{1- Egg-Larval stage:}

Data in Table (1) showed that the duration of egg-larval stage of the parasitoid, M.rufiventris was insignificantly affected recording $7.1 \pm 0.8,7.6 \pm 0.3$ and $7.8 \pm 0.1$ days for three rates (half, recommended and double rate) from bacterial biocide, B.thuringiensis, respectively compared with that recorded in control $7.6 \pm$ 0.1days.While, Amira-Ibrahim (1986) fund that the larval developmental period of the parasitoid, M.rufiventris parasiting on host, $S$. littorals after reared on semi-artificial diet was completed in $7.6 \pm 0.6$ (7-9) days.EL-Maghraby et al. (1988) recorded that the duration of egg-larval stage was greatly affected recording $9.1 \pm 0.1$ days after 
the treatment of the host larvae which treated with B.thuringiensis as compared with that of control $6.8 \pm 0.1$ days that reared on artificial diet. But the duration of egglarval period in control $7.60 \pm 0.1$ days after the treatment of host larvae which, treated with B.thuringiensis as compared with that of the control $6.8 \pm 0.1$ days that reared on artificial diet. Also, the duration of egg-larval period in control $7.60 \pm 0.09$ days was relatively shorter than $8.81 \pm 0.07$ days recorded by Hegazi et al. (1977).

\section{1-2-Pupal stage:-}

The mean duration of pupal stage of M.rufiventris recorded $4.88 \pm 0.08$, $4.80 \pm 0.12$ and $6.57 \pm 0.09$ days, respectively, for the three tested rates [half, recommended and double recommended ] of B.thuringiensis as compared with $4.56 \pm 0.12$ days at the control (able 1 ).

EL-Maghraby et al. (1988) found that the duration of pupal stage was recorded $5.0 \pm 0.1$ days after the host larvae of $S$. littorals were fed on semi artificial diet treated with B.thuringiensis. Also, Amira-Ibrahim (1986) found that the pupal period lasted $4.45 \pm 0.64(4-6)$ days.

\section{3- Total developmental period:}

Also, data in Table (1) indicated that, the mean total developmental period of M.rufiventris parasitizing larvae of cotton leaf worm, S. littorals treated with half, recommended and double recommended rates of Ecotch-bio were $11.96 \pm 0.02$, $12.00 \pm 0.09$ and $12.75 \pm 0.22$ days, but $12.12 \pm 0.10$ days in the control. While, ELMaghraby et al. (1988) found the mean total developmental period of the parasitoid, M.rufiventris after treated $S$. littorals that parasitizing by the parasitoid abovementioned with B.thuringiensis was 14.1 days and 11.9 that recorded in treatment control.

\section{4- Longevity of males and females:}

The mean longevity of M.rufiventris males was $5.10 \pm 0.15,6.68 \pm 0.51$ and $5.08 \pm 0.36$ days for the three rates above-mentioned, respectively compared with 5.88 \pm 0.13 days in the control (Table 1 ).

Average longevity period of females resulted from treatment of parasitized larvae by, M.rufiventris with the three rates B.thuringiensis were $4.94 \pm 0.12,8.80$ \pm 0.56 and $6.32 \pm 0.38$ days, respectively. It was $5.88 \pm 0.31$ dayes in the control. High significant differences were recoded among tested concentrations under the laboratory study. (Table, 1 ). 
Table 1. Effect of different rates of Bacullis thuringensis on some biological aspects of Microplitis rufiventris under laboratory conditions.

\begin{tabular}{|c|c|c|c|c|c|c|c|}
\hline \multirow{2}{*}{\multicolumn{2}{|c|}{ Biological aspects }} & \multicolumn{6}{|c|}{ Application rates of $B$. thuringensis(Mean $\pm \mathrm{SE} /$ day) } \\
\hline & & Control & Half & Recommended & double & L.S.D & \\
\hline \multicolumn{2}{|c|}{ Egg-Larval period } & $7.60 \pm 0.09$ & $7.12 \pm 0.08$ & $7.56 \pm 0.27$ & $7.80 \pm 0.14$ & 0.48 & NS \\
\hline \multicolumn{2}{|c|}{ Pupal stage } & $4.56 \pm 0.12$ & $4.88 \pm 0.08$ & $4.80 \pm 0.12$ & $6.57 \pm .09$ & 2.12 & $* *$ \\
\hline \multicolumn{2}{|c|}{ Total development } & $12.12 \pm 0.1$ & $11.96 \pm 0.02$ & $12.00 \pm 0.09$ & $12.75 \pm .22$ & 0.38 & $* *$ \\
\hline \multirow{2}{*}{ 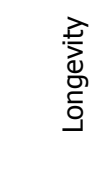 } & $\hat{0}$ & $5.88 \pm 031$ & $5.10 \pm 0.15$ & $6.68 \pm 0.51$ & $5.08 \pm 0.36$ & 1.07 & ** \\
\hline & q & $5.90 \pm 0.31$ & $4.94 \pm 0.12$ & $8.80 \pm 0.56$ & $6.32 \pm 0.38$ & 1.13 & ** \\
\hline \multirow{2}{*}{ 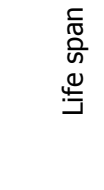 } & $\sigma^{\pi}$ & $18.18 \pm 0.4$ & $15.28 \pm 0.31$ & $18.13 \pm 0.63$ & $18.56 \pm 0.39$ & 1.38 & ** \\
\hline & 우 & $18.22 \pm 0.7$ & $16.18 \pm 0.24$ & $19.30 \pm 0.66$ & $17.72 \pm 0.85$ & 2.02 & ** \\
\hline
\end{tabular}

\section{5- Life span of M.rufiventris/ males and females:}

Data in table (1) showed the mean life span period of M.rufiventris males after treatment, the treated host larvae of $S$. littorals recorded $15.28 \pm 0.31,18.13 \pm$ 0.65 and $18.56 \pm 0.39$ days, respectively as compared with $18.18 \pm 0.42$ in the control. And Results at the same table indicated that the Correspondent mean life span period of parasitoid, M.rufiventris females was $16.18 \pm 0.24,19.30 \pm 0.66$ and17.72 \pm 0.85 days as compared with $18.22 \pm 0.77$ days in the control.

\section{Effect of B.thuringiensis on some biological parameters of M.rufiventris:}

\section{1-Mortality percentage at egg- larvae period:-}

Mortality percentage of egg-larvae period recorded 20, 28 and 40\%, respectively compared with $4.0 \%$ in control. (Table, 2). EL-Maghraby et al. (1988) found that the infection with bacterial, B.thuringiensis alone caused $41.67 \%$ mortality in parasitized host larvae of $S$. littorals that reared on semi artificial diet, but the same authors (2000) found that the bacterial, B.thuringiensis caused lower mortality in four days old second instar larvae of $S$. littorals parasitized with M.rufiventris that fed on castor bean leaves, dipped in different concentrations.Shalaby et al. (2004) found that 
the lowest concentration of the biocide, xentari,( B.thuringiensis) caused $16.67 \%$ mortality of parasitized, $S$. littorals larvae that fed on castor bean.

\section{2-Pupation percentage:}

Data in the same table (2) showed that pupation percentage of M.rufiventris recorded 64,60 and $60 \%$, respectively for the three treatments, as compared with $96 \%$ in the control. Mortality percentage of pupal stage was 16,12 and $8 \%$, respectively, resulted in the treatments as compared with $4 \%$ in the control (Table 2).

Table 2. Effect of different rates of B.thuringiensis on some biological parameters of M.rufiventris under laboratory conditions.

\begin{tabular}{|c|c|c|c|c|c|c|c|c|c|c|c|}
\hline \multirow{4}{*}{ 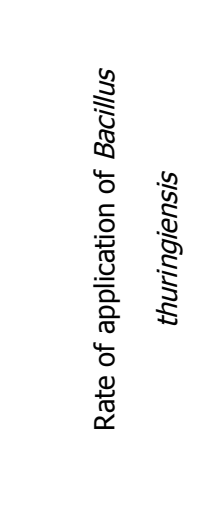 } & \multicolumn{11}{|c|}{ Mortality rate } \\
\hline & \multirow{2}{*}{\multicolumn{2}{|c|}{$\begin{array}{l}\frac{\mathbb{N}}{\pi} \\
\frac{2}{0} \\
\frac{1}{1} \\
\frac{0}{d}\end{array}$}} & \multirow{2}{*}{\multicolumn{2}{|c|}{ Pupation }} & \multirow{2}{*}{\multicolumn{2}{|c|}{ 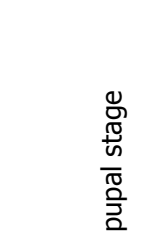 }} & \multicolumn{4}{|c|}{ Adults emergence } & \multirow{3}{*}{$\begin{array}{l}\text { Sex } \\
\text { ratio } \\
\delta: \quad q\end{array}$} \\
\hline & & & & & & & \multicolumn{2}{|c|}{$\sigma^{\lambda}$} & \multicolumn{2}{|c|}{ 우 } & \\
\hline & No. & $\%$ & No. & $\%$ & No. & $\%$ & No. & $\%$ & No. & $\%$ & \\
\hline Half & 10 & 20 & 32 & 64 & 8 & 16 & 16 & 32 & 16 & 32 & $1: 1$ \\
\hline Recommended & 14 & 28 & 30 & 60 & 6 & 12 & 22 & 44 & 8 & 16 & $2.8: 1$ \\
\hline Double & 20 & 40 & 30 & 60 & 4 & 8 & 12 & 28 & 14 & 26 & $0.9: 1$ \\
\hline Control & 2 & 4 & 48 & 96 & 2 & 4 & 24 & 48 & 22 & 44 & $0.9: 1$ \\
\hline
\end{tabular}

No. $=$ Number

$\%=$ percentage

\section{3- Emergence percentage adults:}

Data in table (2) showed that, emergence percentage of M.rufiventris of males in the treatments was 32,44 and $28 \%$, respectively while, it was $48 \%$ in the control. As shown in the same table it was M.rufiventris 32, 16 and $26 \%$, respectively in compared with $22 \%$ in the check.

\section{$\Pi$ - Effect of fungus, Beauvaria bassiana on some biological aspects of} parasitoid, M. rufiventris under laboratory conditions.

\section{1- Egg-Larval period:}

Data presented in table (3) indicated that the duration of egg-larval development of the parasitoid, M.rufiventris parasited the larvae of cotton leaf worm, S. littorals was7.04 $\pm 0.03,7.21 \pm 0.10$ and7.11 \pm 0.22 days at the three rates (half, and double recommended), respectively of B. bassiana as compared with7.60 \pm 0.09 days recorded 
in the control. Also, data in the same table showed that, L.S.D. 0.05 value $(0.39)$ indicated a significant difference found among all different tested rates of the fungus and control.

Table 3. Effect of different rates of the fungus, Beauvaria bassiana on some biological aspects of the parasitoid, Microplitis rufiventris under laboratory conditions.

\begin{tabular}{|c|c|c|c|c|c|c|c|}
\hline \multirow[t]{2}{*}{$\begin{array}{l}\text { Biological } \\
\text { aspects }\end{array}$} & \multicolumn{5}{|c|}{$\begin{array}{l}\text { Application rates of Beauvaria bassiana } \\
\qquad \text { Mean } \pm \mathrm{SE} / \text { day }\end{array}$} & \multicolumn{2}{|c|}{ L.S.D 0.05} \\
\hline & & control & Half & Recommended & Double & & \\
\hline $\begin{array}{l}\text { Egg-Larval } \\
\text { period }\end{array}$ & \multicolumn{2}{|c|}{$7.60 \pm 0.09$} & $7.04 \pm 0.03$ & $7.21 \pm 0.10$ & $7.11 \pm 0.22$ & 0.39 & $*$ \\
\hline Pupal stage & \multicolumn{2}{|c|}{$4.56 \pm 0.12$} & $4.69 \pm 0.11$ & $4.96 \pm 0.16$ & $4.59 \pm 0.06$ & 0.35 & ** \\
\hline $\begin{array}{c}\text { Total } \\
\text { developmental } \\
\text { period }\end{array}$ & \multicolumn{2}{|c|}{$12.12 \pm 0.1$} & $9.92 \pm 0.73$ & 12. $16 \pm 0.13$ & $11.81 \pm 0.07$ & 1.13 & $* *$ \\
\hline \multirow{2}{*}{ Longevity of } & so & $5.88 \pm 031$ & $9.05 \pm 0.72$ & $5.81 \pm 0.20$ & $6.38 \pm 0.22$ & 1.25 & $* *$ \\
\hline & ot & $5.90 \pm 0.31$ & $4.87 \pm 0.09$ & $5.80 \pm 0.51$ & $6.00 \pm 0.45$ & 1.13 & NS \\
\hline \multirow{2}{*}{ Life span } & ro & $18.18 \pm 0.42$ & $20.52 \pm 0.42$ & $16.79 \pm 0.27$ & $18.22 \pm 0.44$ & 1.38 & $* *$ \\
\hline & ot & $18.22 \pm 0.7$ & $15.35 \pm 0.09$ & $26.20 \pm 0.49$ & $18.00 \pm 0.45$ & 2.02 & ** \\
\hline
\end{tabular}

NS=Non Significant

$* *=$ Highly Significant

Hegazi et al. (1977) recorded $10.1 \pm 0.1$ days as the duration of egg-larval period in the control. Also, the same authors found that, differences in the duration of egg-larval period may be due to the host food, host instars and temperature prevailing in host rearing room. While, El-Magrhaby et al. (1988) found that the duration of egg-larval period was $10.4 \pm 0.1$ days after the treatment of host larvae, $S$. littorals with $B$. bassiana as compared with $6.8 \pm 0.1$ days in the control.

\section{2-Pupal stage:}

Data presented in table (3) indicated that the mean duration pupal stage of M.rufiventris was $3.63 \pm 0.11,496 \pm 0.16$ and $4.59 \pm 0.06$ days at the three tested rates (half, recommended and double recommended) of biocide fungus, $B$. bassiana 
respectively, as compared with $4.56 \pm 0.12$ days which recorded in control. L.S.D. value $=0353$ showed a highly significant differences among all tested rates of the biocide and untreated check.

El-Magrhaby et al. (1988) found that the duration of pupal stage recorded $5.3 \pm 0.1$ days after feeding parasitized larvae of $S$. littorals with M.rufiventris on semi artificial diet treated with the fungus, $B$. bassiana.

\section{3-Developmental period:}

Results in table (3) indicated that the mean total developmental period of M.rufiventris parasitizing larvae of $S$. littorals that treated with three rates of biocide, biofly (half recommended and double recommended) fungi, and Beauvaria bassiana were $9.92 \pm 0.37,12.16 \pm 0.13$ and $11.81 \pm 0.07$ days respectively, compared with $12.12 \pm 0.10$ days that recorded in check. There are significant difference found only between half rate of fungi and control. The L.S.D. $._{0.05}=1$.13. El-Magrhaby et al. (1988) found that the total developmental period of parasitoid, M.rufiventris recorded 15.7 days after treatment the host larvae of $S$. littorals with biocide fungi, B. bassiana while it was 11.9 days in control.

\section{4- Longevity period of males and females:-}

Data at the same table (3) showed that the average longevity of adult males of M.rufiventris parasitized larvae of $S$. littorals treated with three rates of $B$. bassianar recorded $9.05 \pm 0.72,5.81 \pm 0.20$ and6.38 \pm 0.22 days, respectively, compared with $5.88 \pm 0.31$ days in the control. While, the mean longevity period of females of M.rufiventris recorded was $4.87 \pm 0.09,5.80 \pm 0.51$ and $6.00 \pm 0.45$ days respectively, for that the rates above-mentioned compared with $5.90 \pm 0.31$ days in the control.

\section{5-Life span of adult males and females:}

Results summarized in Table (3) showed that the mean life span of adult males of M.rufiventris resulted from treated larvae of S.littorals recorded $20.52 \pm$ $0.42,16.79 \pm 0.27$ and $18.22 \pm 0.44$ days, respectively, compared with $18.18 \pm 0.42$ days in the control. L.S.D.values revealed that there was slight significant differences among the three rates of fungus. Data in the same Table indicated that the average life span of females of M.rufiventris was $15.35 \pm 0.09,26.20 \pm 0.49$ and $18.00 \pm 0.45$ days, respectively, compared with $18.22 \pm 0.77$ days in the control. Also, slight significant differences among the three rates of fungus were recorded. 


\section{6-Effect of the fungus, $B$. bassiana on some biological parameters of} M.rufiventris under laboratory conditions.

\section{6-1-Mortality at egg-larval period:}

Data in Table (4) indicated that, mortality percentage of M.rufiventris due to parasitizing larvae of cotton leaf worm treated with different rates of fungus $B$. bassiana was 8,12 and $20 \%$, respectively, as compared with $1.0 \%$ in the control. In this respect, El-Magrhaby et al. (1988) found that percentage mortality of egg-larval period of M.rufiventris parasitized larvae $S$. littorals treated with biocide fungus, $B$. bassiana caused mortality percentage $42.20 \%$.

Table 4. Effect of different of fungus, $B$. bassiana rates on mortality percentage of egg-larvae period, pupation percentage, and mortality percentage of pupal stage, emergence of adult stage and sex ratio of M.rufiventris under laboratory conditions.

\begin{tabular}{|c|c|c|c|c|c|c|c|c|c|c|c|c|}
\hline \multirow{4}{*}{ 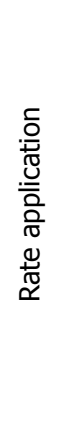 } & \multirow{4}{*}{4} & \multicolumn{6}{|c|}{ Mortality rates } & \multirow{2}{*}{\multicolumn{4}{|c|}{$\begin{array}{l}\% \text { of Adults } \\
\text { emergence }\end{array}$}} & \multirow{4}{*}{$\begin{array}{r}\text { Sexratio } \\
\\
: \text { : }\end{array}$} \\
\hline & & \multirow{2}{*}{\multicolumn{2}{|c|}{$\begin{array}{c}\text { \% Of } \\
\text { egg-larvae }\end{array}$}} & \multirow{2}{*}{\multicolumn{2}{|c|}{ \%Pupation }} & \multirow{2}{*}{\multicolumn{2}{|c|}{$\begin{array}{c}\% \text { of pupal } \\
\text { stage }\end{array}$}} & & & & & \\
\hline & & & & & & & & \multicolumn{2}{|c|}{ Males } & \multicolumn{2}{|c|}{ Females } & \\
\hline & & No. & $\%$ & No. & $\%$ & No. & $\%$ & No & $\%$ & No. & $\%$ & \\
\hline \multicolumn{2}{|r|}{ Half } & 4 & 8 & 46 & 92 & 6 & 12 & 20 & 40 & 20 & 40 & $1: 1$ \\
\hline \multicolumn{2}{|c|}{ Recommended } & 6 & 12 & 44 & 88 & 8 & 16 & 26 & 52 & 10 & 20 & 2.6: 1 \\
\hline \multicolumn{2}{|c|}{ Double } & 10 & 20 & 40 & 80 & 10 & 20 & 26 & 52 & 4 & 8 & $2.6: 1$ \\
\hline \multicolumn{2}{|c|}{ Control } & 1 & 2 & 49 & 98 & 4 & 8 & 23 & 46 & 22 & 44 & $0.95: 1$ \\
\hline
\end{tabular}

No. =Number

$\%=$ percentage

\section{6-2-Pupation percentage:}

Data in the same Table, indicated that, the percentage of pupation of M.rufiventris resulted from treatments was estimated as 92,88 and $80 \%$, respectively, as compared with $98 \%$ in the control.

\section{6-3-Mortality percentage of pupal stage:}

Data in Table (4) showed that, the mortality percentage of M.rufiventris pupae parasitized larvae, $S$. littorals treated with three rates from biocide fungus recorded 12,16 and $20 \%$, respectivelyas compared with $8 \%$ in check treatment.

\section{6-4-Adult emergence percentage of males and females:}

Data in Table (4) indicated that, the percentage of adult male's emergence of M.rufiventris was 40,52 and $52 \%$, respectively and $92 \%$ in the control. Data in the 
same table indicated that females of M.rufiventris was 40,20 and $8 \%$, respectively, compared with $44 \%$ in the control.

\section{6-5-Sex ratio:}

Also, data in the same table showed that, the sex ratio of M.rufiventris adults resulted from $S$. littorals larvae treated with three rates of the fungus $B$. bassiana recorded $(1: 1),(2.6: 1)$ and (2.6:1), respectively, compared with $(0.95: 1)$ in the check.

\section{Ш- Effect of biocide, bioclean (Bacillus thuringiensis + Beauvaria bassiana) on some biological aspects of parasitoid, M.rufiventris under laboratory conditions.}

\section{1- Egg-Larval period:}

Data in Table (5) showed that, the mean period of egg-larval development M.rufiventris parasitized larvae of $S$. littorals ,treated with rates (half, and double recommended rates (half, recommended and double recommended of biocide, bioclean was7, $48 \pm 0.05,7.04 \pm 0.02$ and $7.12 \pm 0.05$ days, as compared with highly significant differences between the7.60 \pm 0.09 days in untreated check.

El-Magrhaby et al. (1988) found that the duration of egg-larval period was $11.2 \pm 0.2$ days after the treatment of host larvae with $B$. thuringiensis $+B$. bassiana as compared with $6.8 \pm 0.1$ days in the control. It was shorter8.81 \pm 0.7 days than that recorded by El-Magrhaby (1984) and El-Magrhaby et al. (1977). The differences in the duration of egg-larval period may be due to the host food, host instars and the temperature prevailing in host rearing room.

\section{2-Pupal stage:}

Results in Table (5) indicated that, the mean duration of pupal stage of the parasitoid, M.rufiventris resulted from the host larvae, $S$. littorals that treated with three rates of biocide bioclean, $B$. thuringiensis $+B$. bassiana was $4.75 \pm 0.15,4.91 \pm 0.06$ and $4.83 \pm 0.05$ days respectively, and $4.56 \pm 0.12$ days in the check. L.S.D. $=(0.302)$ showed that non significant effect between the three tests on the pupal stage and the control. El-Magrhaby et al. (1988)found that, the duration of pupal stage was not affected when larvae treated with bioclean, $B$. thuringiensis $+B$. bassiana compared with $5.1 \pm 0.1$ days in the control.

Data recorded in Table (5) clear that the effect of the three rates (half, recommended and double recommended of the biocide bioclean, $B$. thuringiensis $+B$. bassiana on total developmental period of the parasitoid, M.rufiventris were11.91 \pm $0.22,11.96 \pm 0.05$ and $11.81 \pm 0.05$ days respectively, as compared with12.12 \pm 0.10 days in control once. Also, L.S.D. $=0.38$ value indicated no significant difference between the three rates above- mentioned from biocide bioclean and check treatment 
on total developmental period of the parasitoid, M.rufiventris.But, El-Magrhaby et al. (1988) found that the total developmental period was 16.4 days resulted from treatment the host larvae, $S$. littorals treated with bioclean, $B$. thuringiensis $+B$. bassiana compared with 11.9 days in control treatment.

Table 5. Effect of different application rates of biocide, bioclean (bacterial, Bacillus thuringiensis + fungi, Beauvaria bassiana) on some biological aspects of parasitoid, Microplitis rufiventris under laboratory conditions.

\begin{tabular}{|c|c|c|c|c|c|c|c|}
\hline \multirow{2}{*}{\multicolumn{2}{|c|}{ Biological aspects }} & \multicolumn{4}{|c|}{$\begin{array}{l}\text { Application rates of } B \text {. bassiana }+B \text {.bassiana } \\
\text { Mean } \pm \mathrm{SE} / \text { day }\end{array}$} & \multirow{2}{*}{\multicolumn{2}{|c|}{ L.S.D 0.05}} \\
\hline & & Control & Half & Recommended & Double & & \\
\hline \multicolumn{2}{|c|}{ Egg-Larval period } & $7.60 \pm 0.09$ & $7.48 \pm 0.05$ & $7.04 \pm 0.02$ & $7.15 \pm 005$ & 0.19 & $* *$ \\
\hline \multicolumn{2}{|c|}{ Pupal stage } & $4.56 \pm 0.12$ & $4.75 \pm 0.15$ & $4.91 \pm 0.06$ & $4.83 \pm 0.05$ & 0.30 & NS \\
\hline \multicolumn{2}{|l|}{$\begin{array}{c}\text { Total } \\
\text { developmental } \\
\text { period }\end{array}$} & $12.12 \pm 0.1$ & $11.91 \pm 0.22$ & 19. $96 \pm 0.05$ & $11.81 \pm 0.05$ & 0.38 & NS \\
\hline \multirow{2}{*}{ Longevity } & ro & $5.88 \pm 031$ & $4.59 \pm 0.35$ & $6.03 \pm 0.18$ & $6.52 \pm 0.43$ & 0.99 & $* *$ \\
\hline & O+ & $5.90 \pm 0.31$ & $4.00 \pm 0.00$ & $5.13 \pm 0.13$ & 5.000 .00 & 0.50 & $* *$ \\
\hline \multirow{2}{*}{ Life span } & so & $18.18 \pm 0.42$ & $16.24 \pm 0.31$ & $18.14 \pm 0.32$ & $18.89 \pm 0.32$ & 1.16 & $* *$ \\
\hline & O+ & $18.22 \pm 0.77$ & $17.33 \pm 0.00$ & $17.04 \pm 0.04$ & $17.00 \pm 0.45$ & 1.15 & NS \\
\hline
\end{tabular}

NS=Non Significant $\quad *=$ Significant $\quad * *=$ Highly Significant

\section{3- Total developmental period:}

\section{4-Longevity period of adults of males and females:}

Data in the same Table(5) the average longevity period of adult males of M.rufiventris parasitized of $S$. littorals treated with three rates from biocide bioclean, B. thuringiensis $+B$. bassiana was $4.59 \pm 0.33,6.03 \pm 0.18$ and $6.52 \pm 0.43$ days, respectively, and $5.88 \pm 0.31$ in the control. L.S.D. value $(0.99)$ indicated highly significant differences in longevity of M.rufiventris. In same table the longevity of 
M.rufiventris was $4.00 \pm 0.00,5.13 \pm 0.13$ and $5.00 \pm 0.00$ days, respectively, as compared with $5.90 \pm 0.31$ days in the control.

\section{5-Life span of adult males and females:}

Results showed that in Table (5) the mean life span of adult males of M.rufiventris resulted from larvae, $S$. littorals treated with three rates from the biocide bioclean, recorded $16.24 \pm 0.31,18.14 \pm 0.32$ and $18.89 \pm 0.32$ days, respectively, compared with $18.18 \pm 0.42$ days in the control(Table5). These results revealed that the effect of the rates of the tested compound bioclean was highly significant effect on life span of the parasitoid, M.rufiventris males. Data in the same table, indicated that the average life span of females of M.rufiventris was $17.33 \pm 0.00,17.04 \pm 0.04$ and $17.00 \pm 0.00$ days, respectively, compared with $18.22 \pm 0.77$ days in the control. Also, non significant differences among the effects of three rates of bioclean on the life span of parasitoid, M.rufiventris females.

6-Effect of biocide, bioclean (bacterial, Bacillus thuringiensis + fungi, Beauvaria bassiana) on some biological parameters of M.rufiventris under laboratory conditions.

\section{6-1-Mortality at egg-larval period:}

Data presented in Table (6) indicated that mortality percentage of the egglarval period of $S$. littorals parasitized by the parasitoid, M.rufiventris, treated with rates of biocide bioclean, $B$. thuringiensis $+B$. bassiana recorded 12,28 and $32 \%$, respectively, compared with $2 \%$ recorded in control once. While, El-Magrhaby et al. (1988) found that $S$. littorals treated with $B$. thuringiensis $+B$. bassiana caused a mortality percentage of $6.38 \%$, M.rufiventris.

\section{6-2-Pupation percentage:}

Data in the same table indicated that, the percentage of pupation of M.rufiventris was estimated as 88,72 and $68 \%$, respectively, compred with $98 \%$ in the check .

\section{6-3-Mortality percentage of pupal stage:}

Mortality percentage of M.rufiventris pupae was 4, 12 and 4\%, respectively, while, it was $4 \%$ in the check (Table 6 ).

\section{6-4-Adult emergence percentage:}

Data in Table (6) showed that emergence rate males of M.rufiventris of parasitized larvae of $S$. littorals that fed on castor bean leaves treated with three rates of biocide bioclean, B.thuringiensis $+B$. bassiana was 66,48 and $60 \%$, respectively, while it was $44 \%$ in the control. 
Table 6. Effect of different rates of biocide, bioclean (bacterial, Bacillus thuringiensis + fungi, Beauvaria bassiana) on some biological parameters of M.rufiventris under laboratory conditions.

\begin{tabular}{|c|c|c|c|c|c|c|c|c|c|c|c|}
\hline \multirow[t]{3}{*}{ Rate of application } & \multirow{2}{*}{\multicolumn{2}{|c|}{$\begin{array}{c}\% \\
\text { Mortality } \\
\text { Egg-Larvae }\end{array}$}} & \multirow{2}{*}{\multicolumn{2}{|c|}{$\begin{array}{c}\% \\
\text { pupation }\end{array}$}} & \multirow{2}{*}{\multicolumn{2}{|c|}{$\begin{array}{c}\% \\
\text { Mortality } \\
\text { pupal stage }\end{array}$}} & \multicolumn{4}{|c|}{$\begin{array}{c}\% \\
\text { Adults Emergence }\end{array}$} & \multirow{3}{*}{$\begin{array}{l}\text { Sex } \\
\text { ratio } \\
\qquad: \%\end{array}$} \\
\hline & & & & & & & \multicolumn{2}{|c|}{ Males } & \multicolumn{2}{|c|}{ Females } & \\
\hline & No. & $\%$ & No. & $\%$ & No. & $\%$ & No & $\%$ & No. & $\%$ & \\
\hline Half & 6 & 12 & 44 & 88 & 2 & 4 & 33 & 66 & 9 & 18 & $3.7: 1$ \\
\hline Recommended & 14 & 28 & 36 & 72 & 6 & 12 & 24 & 48 & 6 & 12 & $4: 1$ \\
\hline Double & 16 & 32 & 34 & 68 & 2 & 4 & 30 & 60 & 2 & 4 & $15: 1$ \\
\hline Control & 1 & 2 & 49 & 98 & 4 & 8 & 22 & 44 & 23 & 46 & $0.95: 1$ \\
\hline
\end{tabular}

No. $=$ Number

$\%=$ percentage

Correspondent percentages in females 18,12 and $4 \%$, respectively, compared with $46 \%$ in the control.

\section{6-5-Sex ratio:}

Data in the same Table showed that, the sex ratio of emerged adults of M.rufiventris recorded (1:1), (4:1) and (1.5:1), respectively, compared with (0.95:1) in the check.

\section{REFERENCES}

1. Abd-El-Atty, S.F. 1995. Studies on integrated control grape pests. M.Sc.Thesis. Fac. Agric. Zagazig Univ.109 pp.

2. AL-Tahtawy, M.M.and I.M. Abless. 1972. Thruicide 90 flowable a recent approach to the biological control of Spodoptera littorals (Boisd.) .Z.ang.Entomol. (72):299303.

3. Amira-Ibrahim, A. 1986. Host preference and biological studies of Microplitis rufiventris Kok. a parasite of Spodoptera littorals (Boisd.) in Egypt. Bull. Soc. Entomol. Egypt. (66): 51-56.

4. Bell, J. V. E. G. King, R. Hamell. 1974. Interactions between bollworms, Braconidae parasite and the bacterium Serratia marcescens.Ann.Entomol.Soc.Ann. 67:712-714.

5. Duncan, D.B. 1955. Multiple Ranges and multiple F.test.Biometric (11):1-42.

6. EL-Magraby, M.M.A. 1984. Der Einflußvon Bacillus thuringiensis Berliner auf zwei Wirt- Parasit-Systeme, Spdoptera littoralis (Boisd.)- Microplitis rufiventris Kok, Pieris brassica L. Apanteles glomeratesL. Diss.Landw. Fak.Univ. Gottingen.

7. EL-Magraby, M.M.A., A. Hegab and S. I. Yousif-Khalil. 1988. Interaction between Bacills thuringiensis Berl, Beauveria bassiana (Bals.) Vull. and the host / parasitoid system Spodoptera littorals (Boisd.) Microplitis rufiventris Kok.J. Appl. Entomol. (106): 417-421. 
8. EL-Sufty, R. 1978. Parasitare Veranderungen der Wirts KutiKula durch entomophage Endoparasiten und ihre Bedeutung fur Pilzin fektion.Diss. Landw.Fak. Univ. Gottingen.

9. Hamed, A.R. 1979. Zur wirkung von Bacillus thuringiensis auf parasiten und predatorn von Yponomeuteevonymellus (Lep: Yponomeutidae) (Effects of Bacillus thuringiensis on parasites and predators of Yponomenta euonymellus (Lep: Yponomeutidae). Z .ang. Ent. 87:299-311.

10. Hegazi, E. M., A.M. El-Minshawy and S.M. Hammad. 1977. Suitability of Spdoptera littoralis larvae for development of Microplitis rufiventris.J.Agric.Sci.Camb. (89):659-662.

11. Hochberg, M.E., M.P.Hassell and R.M.May (1990): The dynamics of host parasitoid- pathogen interactions.Am.Nat.135:79-94.

12. Laigo, F.M. and M.Tamashiro. 1967. Interaction between microspodian hymenopterous parasites Apantelrs marginiventris. J. Invertebr. Pathol. 9:546554

13. Pedigo, L.P. 2004. Entomology and Pest Management. Prentice-Hall of India Pvt.Ltd.New Delhi-1100

14. Radwan, S.M.E., F.Fensity. Shalaby, E. H. Abd -El-Karim and E. S. Mansour. 2004. The simultaneous effect of certain recommended insecticides and selective biocides on the changes in the population density of cotton leaf worm and its related bio agents inhabiting cotton fields. Egypt.J.Agric. Res.82 (3)1139-1153.

15. Salama, H.S., F.N.Zaki and A.F. Shraby. 1982. Effect of Bacillus thuringiensis Berliner on parasites and predators of the cotton leaf worm Spdoptera littoralis (Boisd.).J.Appl.Ent.94:488-504.

16. Shalaby, F.F., E.H.Abd-El-Karim, S.H. Radwan and E.S. Mansour 2004. The simultaneous effect of bioinsecticide, chemical insect and their mixtures on both Spdoptera littoralis (Boisd.) and its endo parasitoid, Microplitis rufiventris Kok.Egyptian J. Agric. Res. 82(3):1155-1173.

17. Snedecor, G.W. 1970. Statistical method applied to experiments in agriculture and biology Lowa.State. Press. U.S.A. 534 pp.

18. Tawfik, M.F.S., M.Hafez and A.A.Ibeahim. 1980. Immature stages of Microplitis rufiventris Kok.Dutsch.Entomol.Z.N.F. (27):39-50.

19. Temerak, S.A. (1980): Detrimental effects of rearing a braconid parasitoid on the pink borer larvae inoculated by different concentrations of the bacterium Bacillus thuringiensis Berliner.J.Appl.Ent, 89: 315-319.

20. Temerak, S.A. 1982. Interaction between the bacterial pathogen, Bacills thuringiensis and the braconid, Bracon brevcornis larvae as host insect in response to five temperatures.Anz. Schadl. Pfanze. Un Welt. (55):137-140. 


\title{
تاثيربعض المبيدات الحيوية على بعض الصفات البيولوجية
}

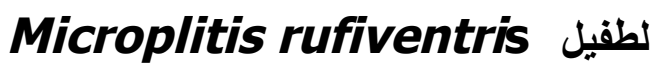$$
\text { صلاح فريد عبد العاطى }
$$$$
\text { قسم المكافحة البيولوجية - معهد بحوث وقاية النباتات- مركز البحوث الزراعية . }
$$$$
\text { أجريي هذا البحث بغرض در اسة تأثير المبيدات الحيوية على بعـض الصــفات البيولوجيــة }
$$$$
\text { لطفيل Microplitis rufiventris }
$$

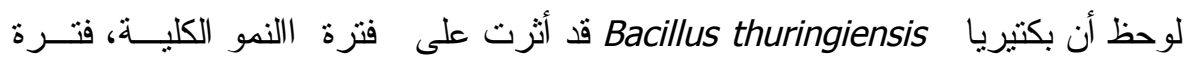

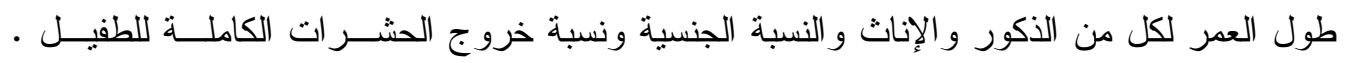 \\ وسبيت البكتيريا Bacillus thuringiensis نسبة موت لكل من طور البيض و اليرقـات ب بإســتعمال

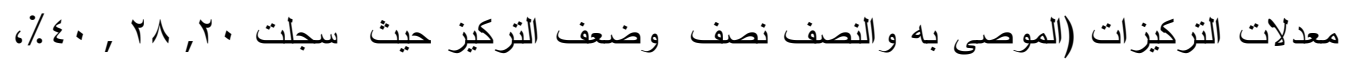

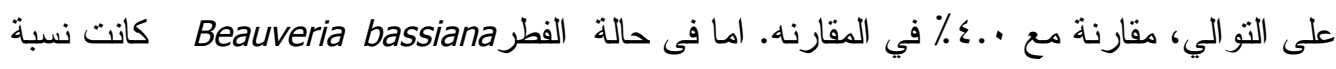

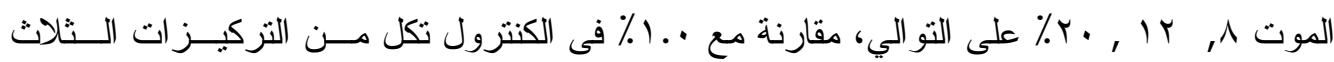 \\ سابقة/لإكر .

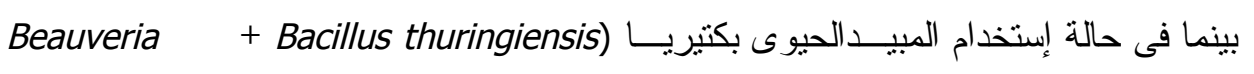 \\ (bassiana

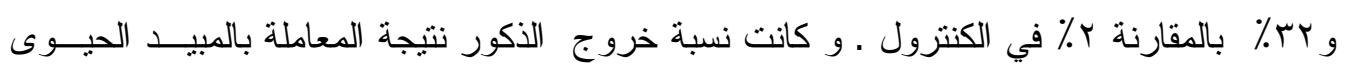

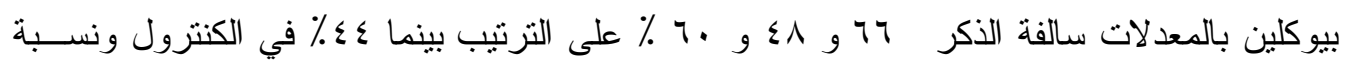

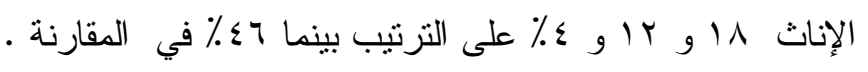

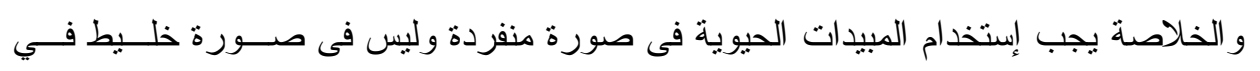

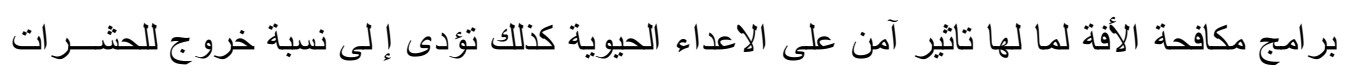

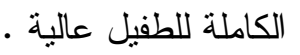

